\title{
Implementation of Google Forms in ECE to Face Digital Era
}

\author{
Naili Rohmah, Mohamad Hariyono, Muh Shofiyuddin \\ Universitas Islam Nahdlatul Ulama Jepara \\ e-mail: naili@unisnu.ac.id
}

\begin{abstract}
The 4.0 industrial revolution demands individuals to keep up with the development of the digital world. The progress of the digital world is not only enjoyed by those who work in technology and industry but also everyone living in the world. The development of digital technology today has been included in the world of education, including Early Childhood Educatin (ECE). ECE must be able to apply digital technology products in this digital era as part of educational conversion. One example of technology in digital era is the change of manual questionnaires into digital questionnaires. Digital questionnaires that can be easily applied in ECE are Google forms. The reason for choosing Google forms as a digital questionnaire for ECE is that, Batubara (2016) says that Google forms can be as one of recommended software to make online measurements. The use of Google forms for ECE in the digital era is to: 1) online registration forms for new students' admissions; 2) activity registration form; 3) survey users of early childhood services; 4) an alternative way to make digital suggestion boxes; 5) gather criticism and suggestions for the advancement of ECE Institutions; 6) collecting parental desires for children's education or parenting activities; and 7) tools of developing competency of educators through research. The Google forms have several advantages that a manual questionnaire does not have, namely paperless, environmentally friendly, time efficient, labor costs, accurate recapitulation of respondents' answers, and practical.
\end{abstract}

Keywords: Digital era, ECE, Google Forms

\section{INTRODUCTION}

The 4.0 industrial revolution demands individuals to keep up with the development of the digital world. As being wrtitten in Kemendikbud (2017) that digital revolution is a change of analogue electronical and mecanical technology into digital technology. The digital era changes or converts simple technology into digital technology. Some examples of technology conversion are letters into emails, phones being cellphones, typewriters into computers, and books become electronic books (ebooks). In this era, individuals being able to follow the pace of development can survive, while they who do not want to follow the progress will be left behind by many things. The progress of the digital world is not only enjoyed by those who work in technology and industry but also by everyone living in the world. The development of digital technology today has been included in the world of education. Rohmah and Aflahani (2018) states that education needs a help from technology to make learning process conducted easier. These technological changes are very useful if being used wisely, including the use of questionnaires.

So far, the questionnaire has only been used in companies and the scope of academics to conduct research. Sugiyono (2015) states that Questionnaire is one of data collection technique which is done by giving a set of questions or wrtitten questions to the respondances to answer. Along with the times, the questionnaire became an inevitable need in Education Institute. The use of questionnaires in Early Childhood Education (ECE) institutions can be used to: 1) fill in new student registration forms; 2) get criticism and suggestions for ECE development; 3) confirmation of the participation of parents / students in event activities; 4) become a 
forum for stakeholder aspirations; and 5) become one of the research data collection techniques.

Questionnaire in the form of paper is a kind of manual technology. The life of the digital era is characterized by starting to abandon manual technology and switch to digital technology. There are several advantages of digital questionnaires compared to manual questionnaires, including: 1) in terms of time, manual questionnaires require more time to spread and receive back with a long duration, while digital questionnaires with just one touch we can use time to do other things; 2) in terms of costs, manual questionnaires require multiplication that requires money, while digital questionnaires only use a small quota and can be directly distributed to many targets; 3) in terms of power, digital questionnaires require a lot of energy to meet respondents once at a time, but with a digital questionnaire it does not require a lot of energy because it can be controlled remotely; and 4) in terms of data processing, manual questionnaires must be manually input and calculate one-to-one scores, while digital questionnaires directly provide the results of respondents' responses. One of the digital questionnaire products is Google forms. Batubara (2016) says that Google forms can be as one of recommended software to make online measurements.

\subsection{ECE in Digital Era}

ECE is a form of education focussing on the foundation for growth and development. Suyadi (2014) states that both motoric coordination, emotional intelligences, multiple intelligence, and spiritual intelligence are according to the uniqueness and growth of early childhood, ECE implementation is adjusted to the child's developmental stage. It is realized or not, since the child is born, he has ready learned. Activities in ECE institutions focus on: 1) active, hands-on learning; 2)conceptual learning that leads to understanding along with acquisition of basic skills; 3) meaningful, relevant learning experiences; 4) Interactive teaching and cooperative learning; and 5) a broad range of relevant content, integrated across traditional subject matter divisions (Bredekamp, et al 1992).

ECE Institutions are institutions that protect children in the age of 0 to 6 years by providing educational stimulation as one of their activities. In ECE Institutions, Activities provided include activities for the development of religious moral, physical motoric, cognitive, language, social emotion, and art. Both formal and non-formal levels are given development activities in accordance with the stages of age.

The occurrence of a manual era shift into a digital era requires ECE Institute to be able to follow its progress. It will be very difficult if ECE institutes refuse digital technology products for the Institute development. Starting from learning activities, communication between teachers and parents, reporting to the Office must not be separated from digital technology.

The use of digital technology can help the Institution in the field of promotion, preparation of stimulation activities for children's education, related service reporting, parenting, stakeholder communication, and the delivery of information quickly and easily. In the digital era, ECE institute use online registration for new students, online parenting, online growth and reporting, selfdevelopment of educators and students, digital activity participation questionnaires, and submission of criticism and suggestions for school development.

This era, ECE institutions allow parents to monitor children's growth and development from the place they are as the fact that not all parents of students have a lot of time to wait for children in school. Meanwhile, the easy way provided by digital technology is expected not to exclude the obligations of parents as teacher and friends for early childhood.

\subsection{Google Forms}

Google form is one of the default features of Google. Now, everyone has an Android smartphone. The smartphone is directly connected to Google so that Google form is decided as the alternative way in order to make the selected digital questionnaire. Batubara (2012) states that Google forms are suitable to be used by students, teachers, lecturers, and professionals who like to create a quiz, form and online survey. Another reason of choosing Google forms as a digital questionnaire is because Google form is a free application. Google form is a free service from Google, which emulates an online survey system (Kim \& Park 2012.

The procedure of creating Google forms is not too difficult. Besides, how to fill in Google forms is also easy. The main requirement for creating Google forms is having a Gmail account for the creator. Furthermore, Google forms can be created through computers, laptops, even 
smartphones. It is recommended that beginners use a laptop or computer for ease of use.

The steps of creating the Google form are as follows: 1) open a Gmail account, for beginners it is recommended to use a laptop or computer for the easiness of use; 2) click on the box-shaped Google application icon from 9 points next to a profile photo of Gmail account; 3) click the purple forms icon; 4) after opening it, choose a blank worksheet; 5) type the title of the questionnaire in the formless title; 6) describe the purpose of making the questionnaire in the form of description section; 7) make a question on the writing of an untitled question; 8) choose the answer option to the right of the question; 9) turn on the option "must be filled" if the question must be filled; 10) the image of the trash can be clicked if the question wants to be deleted; 11) select the duplicate icon if you want to copy and paste the question and answer on the number after that; 12) when you have finished, click the eye image to see a preview results of the questionnaire; 13) click the send button if the questionnaire is finished and can be distributed; 14) the command box section of the send button has a menu option to shorten the URL; 15) copy the URL, then send it via email or other social media; and 16) google forms based digital questionnaires are ready and can be used.

In order to make it easier in terms of visualization, the following is presented in Picture 1 in the form of the initial appearance of Google Form and some default tool functions.

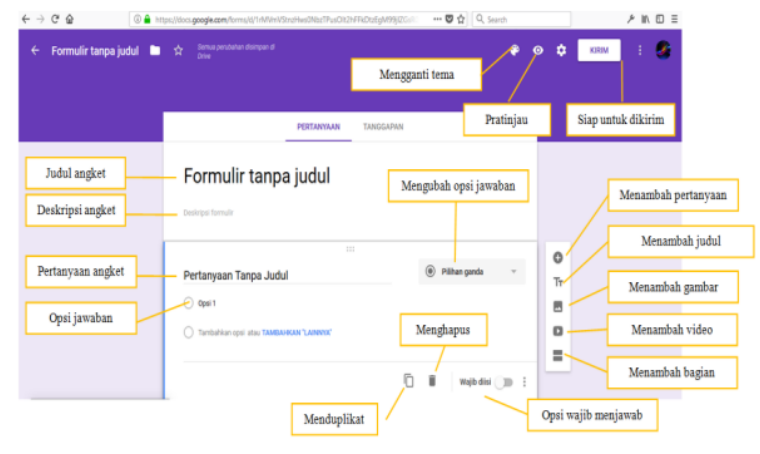

Picture 1. Menus on the Google forms

\subsection{Utilization of Google Forms in ECE}

Google forms are not only used for research or company needs but also other needs and benefits. There are some benefits of Google form when it is applied in ECE. Google forms are useful for: 1) online registration forms for new students; 2) activity registration form; 3) survey users of early childhood services; 4) alternative to make digital suggestion boxes; 5) collect criticism and suggestions for the advancement of ECE Institutions; 6) collecting parental wishes for education or child parenting activities; and 7) means of developing competency of educators through research.

In every beginning of school year, ECE institutions always open registration for new students. The excellent ECE institution will certainly have a problem to handle the surge of new students. In order to facilitate the process of registering children without having to go through the long queue process, ECE institution can create an online registration form through Google forms. After having registered, students who meet the requirements can re-register or conduct orientation activities at their new institution. Making online registration forms through the Google forms is not only for large institutions, but also can be used for ECE institutions with various scales.

Activities in ECE have routine activities carried out every day and supporting activities which are implemented incidentally. Examples of incidental activities are tourism activities or visits to profession places. Sometimes, this supporting activity becomes a dilemma if the activity plan requaires parents to choose the purpose of the activity. An alternative way to invite parents to choose children's activities is by spreading Google forms, then only need to wait for the recapitulation of the majority of parents to choose which activities they want.

Google forms can be used as a means of surveying the use of ECE services. Google forms allow questionnaires to provide options that it is not obligatory to write names so that respondents who will provide input on ECE services are not reluctant. Google forms can be set so that the confidentiality principle of the respondent's identity is safed. It will be different when giving comments about ECE services is directly expressed.

Making a Google forms based digital suggestion box can be used as an alternative media to deliver suggestions. Google forms can be set only by making a question with a choice of answers in the form of paragraphs, so that respondents can provide a description of the suggestions without having to come to school or feel bad. Google forms can be as a bridge for respondents to provide advices to ECE institutions. 
Every educational institution will always get criticism and suggestions from stakeholders. Criticism and suggestions are aimed in developing and advancing the institutions. Between the advisor and the recipient of suggestion and criticism sometimes feels awkward, many reasons are underlying and the general one is feeling not good. In order to make this gap better, ECE institution can create a Google form that contains criticism and suggestions. There are many answer options, so it is possible for ECE institutions to make many forms of Google forms as needed.

The use of Google forms in ECE institutions can be applied to various things, some of them are getting responses about parental desires for child education that are undertaken in ECE and it is also possible to get a response about parenting models made by parents and the institutions. The results of Google forms can be as a mediator and a solution for the stimulating integration of child's development in ECE and at home.

Being an ECE educator is not a limit for a person to stop doing research. It is precisely by becoming an educator, the problem is more complex. These problems can be written into a study. If the study uses a questionnaire as a data collection technique, ECE educators can use Google forms. As the fact that being an ECE educator get the relatively low salary, as well as efficient use of time, costs and energy, making Google forms can be an alternative solution for them.

\section{CONCLUSION}

ECE in digital era should have converted manual technology into digital technology. Google form is as one of the conversion results from manual technology which previously was a paper form questionnaire into paperless one. The use of Google forms based digital questionnaires can be a solution to overcome the limitations of time, cost, and personnel in ECE institutions. The Google forms have several advantages which a manual questionnaire does not have, namely paperless, environmentally friendly, time efficient, labor costs, accurate recapitulation of respondents' answers, and practical.

The presence of technology which facilitates our work must be used wisely. The existence of Google forms is expected not to be the reason for ECE institutions and parents not to meet each other. Google forms only as a means of facilitating service delivery. Google forms cannot replace face-to-face meetings between educators and parents to provide progress reports and exchange information on students. Reporting the results of children's development reports will certainly be better if being given directly from school to parents, so that there is two-way communication to discuss about children's growth and development.

\section{REFERENCES}

[1] Batubara, Hamdan Husein. (2016). Penggunaan Google Form sebagai Alat Penilaian Kinerja Dosen di Prodi PGMI UNISKA MUHAMMAD Arsyad Al Banjari. Al-bidayah: Jurnal Pendidikan Dasar Islam, 8 (1)

[2] Bredekamp, S. dkk. (1992). What Does Research Say About Early Childhood Education?

[3] Kemendikbud. (2017). Mendidik anak di era digital.

[4] Kim, Dong-Gook DK \& Park, Changwoo. (2012). Gender differences in the effectiveness of google forms in class. Journal of instructutional pedagogies, 7 (1)

[5] Rohmah, Naili \& Aflahani, Ari Purnomo Endah. (2018). Optimalisasi pembelajaran anak usia dini melalui pemanfaatan teknologi. Prosiding Sewindu APG PAUD. Bandung 2829 Juli 2018

[6] Sugiyono. (2015). Metode Penelitian Pendidikan. Bandung: Alfabeta

[7] Suyadi. (2014). Teori Pembelajaran Anak Usia Dini: dalam kajian Neurosains. Bandung: PT Remaja Rosdakarya 